\title{
PENGARUH SIKAP MOTIVASI DAN LINGKUNGAN TERHADAP NIAT BERWIRAUSAHA (STUDI PADA MAHASISWA PERGURUAN TINGGI DI WILAYAH KABUPATEN SUKOHARJO)
}

\author{
Agesti Indah Frasiska ${ }^{1}$ \\ Bambang Nur Cahyaningrum ${ }^{2}$ \\ Yoppi Syahrial $^{3}$ \\ Fakultas Ekonomi, Universitas Veteran Bangun Nusantara Sukoharjo ${ }^{123}$ \\ agesti.indah17@gmail.com ${ }^{1}$ \\ bambangnurcahyaningrum@gmail.com²
}

\begin{abstract}
This study aims to determine the effect of attitude, motivation, and environment on entrepreneurial intentions. The sample of this study were active undergraduate students (S1) of tertiary institutions in the Sukoharjo Regency. With the number of respondents 86 people. The analytical tool used to determine the effect between the independent and dependent variables using SPSS. Hypothesis testing in this study uses multiple linear analysis. Based on the results of the analysis showed that the variables of attitude, motivation have a positive and significant effect on entrepreneurial intentions. Meanwhile, environmental variables do not significantly influence to entrepreneurial intentions.
\end{abstract}

Keywords: attitude, motivation, environment, and entrepreneurial intention

\section{PENDAHULUAN}

Pandemi virus covid-19 yang meluas menyebabkan berbagai hal terkena dampaknya, banyak perusahaan yang gulung tikar, adanya PHK massal menyebabkan angka pengangguran meningkat. Setiap harinya banyak para pencari kerja namun lowongan pekerjaan yang tersedia tidak sebanding dengan pencari kerja, sehingga semakin banyak lagi pengangguran. Kondisi seperti ini dapat dikurangi dengan kita berusaha menciptakan lapangan pekerjaan, khususnya mahasiswa yang memiliki kreatifitas dan bekal ilmu yang diperolehnya di dunia perkuliahan, sebaiknya memiliki mental wirausaha. Menurut data BPS tahun 2020, jumlah wirausaha di Indonesia pada tahun 2020 sebanyak $3,47 \%$ dari populasi penduduk di Indonesia sebesar 270 juta jiwa, dimana $68,75 \%$ kategori tersebut masuk dalam usia produktif, dengan 69,90 juta jiwa atau 25,87\% masuk dalam 

http://journal.univetbantara.ac.id/index.php/jbfe

generasi millennial dan generasi $\mathrm{Z}$ sebanyak 75,49 juta jiwa atau setara dengan 27,94\% dari populasi. Angka rasio wirausaha di Indonesia sebesar 3,47\%, angka tersebut masih rendah apabila dibandingkan dengan negara Thailand yang sebesar 4,26\%, Malaysia sebesar 4,74\%, dan Singapura sebesar 8,76\%.

Fenomena yang terjadi di Indonesia guna meningkatkan serta menciptakan para wirausaha baru didorong dengan munculnya rasa niat berwirausaha dalam diri individu, kewirausahaan merupakan salah satu faktor penunjang yang dominan dalam segi pembangunan sosial ekonomi (Caulibali, Erbao, Mekongchou, 2018). Menurut Fourqoniah (2015) intensi berwirausaha adalah terdorongnya seseorang memilih untuk melaksanakan atau tidak melaksanakan sesuatu tindakan berupa memulai atau membentuk bisnis.

Salah satu faktor yang mempengaruhi niat berwirausaha adalah sikap. Sikap merupakan suatu tindakan untuk merespon keinginan yang muncul dalam diri yang dipengaruhi oleh faktor-faktor obyek disekelilingnya (Sumadi \& Sulistyawati, 2017). Sikap yang layak digambarkan oleh para mahasiswa mengenai kewirausahaan akan memunculkan ide kreatif, inovatif tersendiri dalam menciptakan suatu usaha (Walipah, 2016). Penelitian mengenai pengaruh sikap terhadap niat berwirausaha juga pernah diteliti oleh Pormes \& Sipakoli (2019).

Faktor lain yang mempengaruhi niat berwirausaha adalah motivasi. Motivasi adalah bentuk dorongan atau keinginan agar tercapai suatu yang dituju. Motivasi yang mumpuni akan mendorong seseorang untuk memiliki tekad dalam hal berwirausaha, tetapi apabila terlalu kuat motivasi akan berpengaruh negatif terhadap efisiensi usaha tersebut (Aidha, 2016). Penelitian motivasi terhadap niat berwirausaha pernah diteliti oleh Amadea \& Riana (2020).

Faktor lainnya yang mempengaruhi niat berwirausaha adalah lingkungan. Secara garis besar lingkungan mencakup lingkungan keluarga, lingkungan teman sepermainan, dan panutannya. Lingkungan menurut Prawoto \& Affandi (2020) merupakan sekumpulan individu yang saling mempengaruhinya. Pada penelitian ini pernah diteliti oleh Zain et al., (2010) dengan hasil penelitian lingkungan berpengaruh positif dan signifikan terhadap niat berwirausaha.

Penelitian ini mengacu pada penelitian Sumadi \& Sulistyawati (2017), dengan variabel independennya sikap, motivasi, dan lingkungan, sedangkan variabel dependennya adalah niat berwirausaha. Berdasarkan latar belakang di atas, judul penelitian yang digunakan penulis adalah "Pengaruh Sikap Motivasi dan Lingkungan Terhadap Niat 

http://journal.univetbantara.ac.id/index.php/jbfe

Berwirausaha (Studi Pada Mahasiswa Perguruan Tinggi Di Wilayah Kabupaten Sukoharjo)".

\section{RUMUSAN MASALAH}

1. Bagaimana pengaruh sikap terhadap niat berwirausaha?

2. Bagaimana pengaruh motivasi terhadap niat berwirausaha?

3. Bagaimana pengaruh lingkungan terhadap niat berwirausaha?

\section{TINJAUAN PUSTAKA DAN PERUMUSAN HIPOTESIS}

\section{Niat Berwirausaha}

Niat berwirausaha adalah keadaan berfikir secara logis yang menunjukkan sikap seseorang ke arah pengembangan, kemudian merealisasikannya ke dalam konsep bisnis (Nurshito \& Nugraha, 2013). Niat berwirausaha menggambarkan kegigihan setiap orang untuk memulai tindakan dalam memulai usaha, niat berwirausaha sangat diperhatikan dalam proses memulai suatu usaha (Akhtar, 2011). Niat berwirausaha adalah langkah seseorang untuk tertarik dalam mendirikan usaha, yang disusun secara terstruktur. Dari definisi-definisi di atas, dapat disimpulkan bahwa niat berwirausaha merupakan langkah awal yang dilakukan oleh seseorang dalam mendirikan usaha, kemudian dituangkan dengan rencana yang terstruktur dalam membangun usaha.

Sikap

Sikap merupakan dorongan dalam menunjukkan reaksi menanggapi resiko yang ada saat memulai suatu usaha (Samuel, 2013). Sikap adalah reaksi seseorang menanggapi suatu objek tertentu yang disertai gagasan, yang diungkapkan dan rasa emosional seseorang, yang ditunjukkan berupa rasa suka-tidak suka, setuju-tidak setuju. Sikap adalah tindakan seseorang dalam menunjukkan perasaannya, berupa perasaan suka atau tidak suka terhadap suatu hal (Jaya, 2016). Berdasarkan definisi- definisi di atas dapat disimpulkan bahwa sikap merupakan bentuk penilaian, perasaan, respon serta tindakan seseorang terhadap suatu objek. Dengan demikian hipotesis yang dapat dirumuskan adalah $\mathrm{H}_{1}$ : Sikap berpengaruh positif dan signifikan terhadap niat berwirausaha.

\section{Motivasi}

Motivasi merupakan dorongan yang muncul secara sadar, untuk melakukan tindakan, dalam rangka mewujudkan sesuatu yang ingin dicapainya (Rosmiati et al., 2015). Motivasi berwirausaha merupakan dorongan yang memadai dalam menunjukkan semangat berwirausaha, namun semangat yang berlebihan akan memiliki pengaruh negarif terhadap 

http://journal.univetbantara.ac.id/index.php/jbfe

kegiatan berwirausaha (Aidha, 2016). Motivasi adalah segala sesuatu yang menjadi dorongan seseorang dalam melakukan sebuah tindakan dan memberikan kekuatan untuk mencapai apa yang diinginkan (Tama, 2010). Dari definisi-definisi di atas, dapat disimpulkan bahwa motivasi merupakan dorongan ataupun keinginan yang muncul dalam diri individu untuk melakukan tindakan agar tercapai tujuan yang diinginkannya. Dengan demikian hipotesis yang dapat dirumuskan adalah $\mathrm{H}_{2}$ : Sikap berpengaruh positif dan signifikan terhadap niat berwirausaha.

\section{Lingkungan}

Lingkungan terbagi menjadi dua, yaitu lingkungan primer dan sekunder. Lingkungan primer adalah interaksi hubungan yang paling erat dengan seseorang, yaitu lingkungan keluarga, lingkungan sekunder imteraksi yang lebih longgar, seperti pertemanan (Wibowo, 2011). Lingkungan adalah kegiatan individu yang saling mempengaruhinya (Prawoto \& Affandi, 2020). Lingkungan adalah hal yang berkaitan dengan alam sekitarnya yang berada di luar diri individua atau manusia, lingkungan bersifat fisiologis, psikologis, maupun sosiostruktural (Suharti et al., 2021). Dari definisi- definisi di atas dapat disimpulkan bahwa definisi lingkungan terbagi menjadi dua ialah lingkungan primer maupun sekunder.

\section{Niat Berwirausaha}

Niat berwirausaha adalah keadaan berfikir secara logis yang menunjukkan sikap seseorang kearah pengembangan dan merealisasikannya kedalam konsep bisnis (Nurshito \& Nugraha, 2013). Niat berwirausaha menggambarkan kegigihan setiap orang untuk memulai tindakan dalam usaha yang sangat diperhatikan dalam proses memulai suatu usaha (Akhtar, 2011). Niat berwirausaha adalah langkah seseorang untuk tertarik dalam mendirikan usaha yang disusun secara terstruktur. Dari definisi-definisi di atas, dapat disimpulkan bahwa niat berwirausaha merupakan langkah awal yang dilakukan oleh seseorang dalam mendirikan usaha, kemudian dituangkan dengan rencana yang terstruktur dalam membangun usaha. Dengan demikian hipotesis yang dapat dirumuskan adalah $\mathrm{H}_{3}$ : Lingkungan berpengaruh positif dan signifikan terhadap niat berwirausaha.

Digambarkan dalam bentuk model penelitian sebagai berikut: 


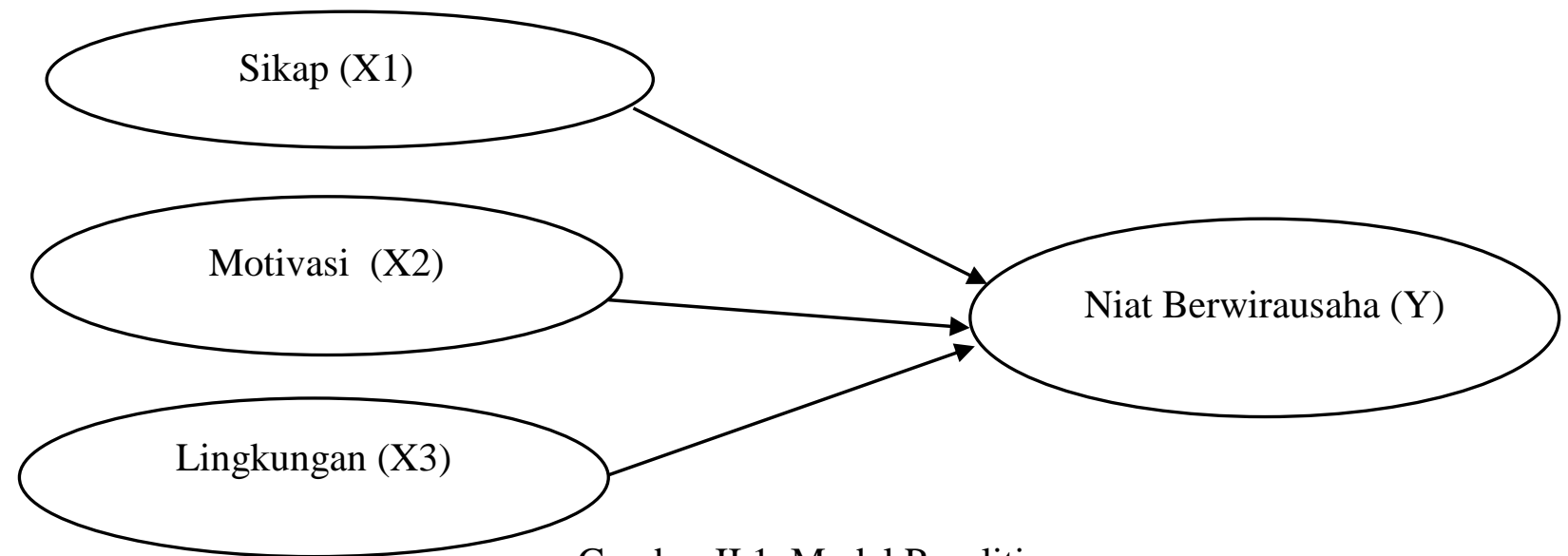

Gambar II.1. Model Penelitian

\section{METODE PENELITIAN}

\section{Populasi dan Sampling}

Populasi dalam penelitian ini adalah mahasiswa aktif perguruan tinggi di wilayah Sukoharjo. Sampel yang digunakan dalam penelitian ini adalah mahasiswa aktif perguruan tinggi di wilayah Kabupaten Sukoharjo, sebanyak, 75 orang. Pengambilan sampel dalam penelitian ini menggunakan metode purposive sampling, penarikan sampel secara purposive merupakan teknik penentuan sampel dengan pertimbangan tertentu atau seleksi khusus (Space, 2014). Karakteristik responden dapat disajikan dalam tabel IV.2 sebagai berikut.

Tabel 1. Distribusi Karakteristik Responden

\begin{tabular}{ccc}
\hline Karakteristik & Frekuensi & Persentase (\%) \\
\hline Perempuan & Jenis Kelamin & \\
Laki- laki & 65 & $75,6 \%$ \\
& 21 & $24,4 \%$ \\
20 tahun & Usia & \\
21 tahun & 4 & $4,7 \%$ \\
22 tahun & 43 & $50 \%$ \\
23 tahun & 27 & $31,4 \%$ \\
24 tahun & 10 & $11,6 \%$ \\
& 2 & $2,3 \%$ \\
Universitas Veteran Bangun & Asal Perguruan Tinggi & $84,9 \%$ \\
Nusantara Sukoharjo & 73 & $11,6 \%$ \\
Universitas Muhammadiyah & 10 & $3,5 \%$ \\
Surakarta & 3 & $100 \%$ \\
STIE Surakarta & Mahasiswa Aktif S1 & $100 \%$ \\
Ya & 86 & \\
$\geq 6$ & Semester & 86 \\
\hline
\end{tabular}


http://journal.univetbantara.ac.id/index.php/jbfe

\section{Definisi Operasional Dan Pengukuran Variabel}

Setiap pernyataan dalam penelitian ini dinilai dengan menggunakan skala likert 5 opsi penilaian antara lain : STS (Sangat Tidak Setuju ), TS (Tidak Setuju), N ( Netral), S (Setuju), SS (Sangat Setuju). Definisi dari masing-masing variabel yang digunakan dalam penelitian ini adalah sebagai berikut:

\section{Sikap}

Sikap adalah kecenderungan seseorang dalam merespon obyek-obyek disekitarnya (Sumadi \& Sulistyawati, 2017). Dalam penelitian ini indikator sikap menggunakan 4 item pernyataan, yang diadopsi dari Sumadi \& Sulistyawati (2017).

2. Motivasi

Motivasi adalah dorongan atau keinginan untuk mencapai tujuan yang dinginkan menurut Pormes \& Sipakoly (2019). Dalam penelitian ini indikator motivasi terdiri dari 5 item pernyataan, yang diadopsi dari Sumadi \& Sulistyawati (2017).

3. Lingkungan

Lingkungan merupakan alam sekitar yang berada disekitar diri individu maupuan manusia Suharti et al., (2021). Dalam penelitian ini indikator lingkungan terdapat 3 item pernyataan, yang diadopsi dari Sumadi \& Sulistyawati (2017).

4. Variabel Dependen Niat Berwirausaha

Niat berwirausaha adalah kegigihan ataupun tekad seseorang untuk menjadi seorang wirausaha (Nurshito \& Nughroho, 2013). Dalam penelitian ini indikator niat berwirausaha, menggunakan 3 item pernyataan yang diadopsi dari Sumadi \& Sulistyawati (2017).

\section{ANALISIS DAN PEMBAHASAN}

\section{Hasil Uji Instrumen Penelitian}

Tabel 2.

KMO and Bartlett's Test

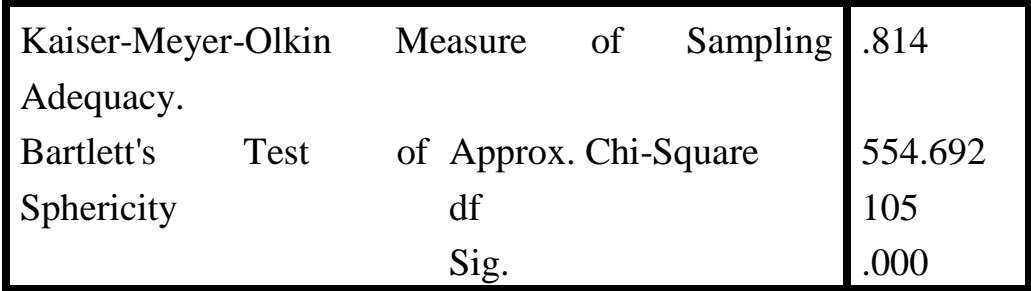

Sumber : Data Primer yang diolah, 2021 
http://journal.univetbantara.ac.id/index.php/jbfe

Tabel 2 uji validitas yang dilakukan menunjukkan hasil nilai KMO Measure of Sampling Adequacy (MSA) dalam penelitian ini sebesar 0,816. Karena KMO MSA di atas 0,50, serta nilai Barlett's Test of dengan Chi- Square $=554,692$ dan signifikan pada 0,000, dapat disimpulkan bahwa uji analisis faktor dapat dilanjutkan.

Tabel 3. Hasil Uji Reliabilitas

\begin{tabular}{|l|l|}
\hline Variabel & Cronbach's Alpha \\
\hline Sikap & .671 \\
\hline Motivasi & .822 \\
\hline Lingkungan & .654 \\
\hline Niat Berwirausaha & .824 \\
\hline
\end{tabular}

Sumber: Data Primer yang diolah, 2021

Dari tabel 3 dapat disimpulkan bahwa secara umum semua variabel penelitian dinyatakan reliabel, karena mempunyai nilai Cronbach's Alpha $\geq 0,60$.

\section{Hasil Uji Hipotesis}

Untuk menguji hipotesis dalam penelitian ini menggunakan metode analisis linear berganda. Berikut ini tampilan model regresi dengan menggunakan bantuan SPSS 22:

Coefficients $^{\mathrm{a}}$

Tabel 4. Hasil Analisis Regresi Linear Berganda

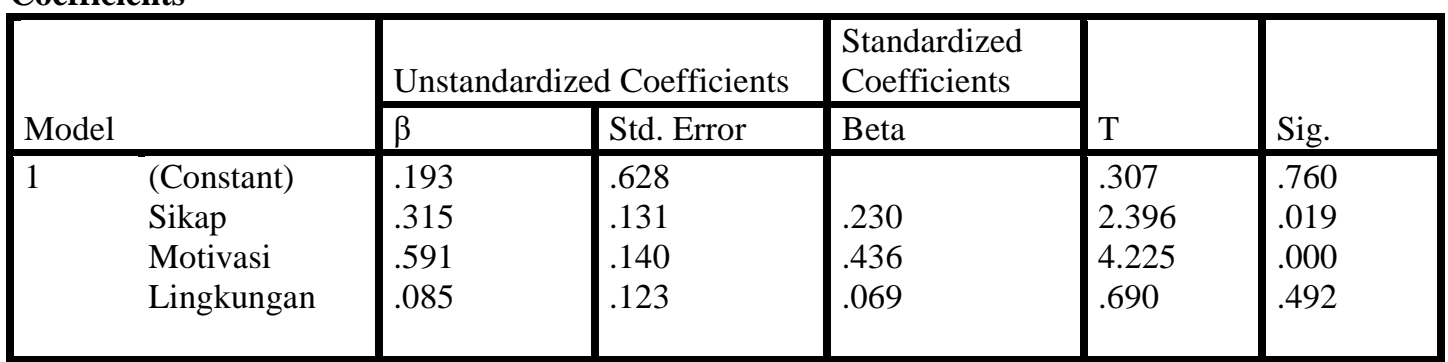

Sumber: Data Primer yang diolah, 2021

Dari tabel 4 menunjukkan bahwa kolom $\beta$ pada constant adalah 0,193 sedangkan nilai sikap 0,315 , nilai motivasi 0,591 , dan nilai lingkungan 0,085 . Model regresinya dapat ditulis sebagai berikut :

$$
\begin{gathered}
\mathrm{Ni}=\mathrm{a}+\mathrm{b}_{1} \mathrm{Si}+\mathrm{b}_{2} \mathrm{Mo}+\mathrm{b}_{3} \mathrm{Lin}+\mathrm{e} \ldots \ldots \ldots \ldots \\
\mathrm{Ni}=0,193+0,315 \mathrm{Si}+0,591 \mathrm{Mo}+0,085 \mathrm{Lin}
\end{gathered}
$$

Tabel 5. Hasil Koefisien Determinasi

\begin{tabular}{|l|l|l|l|l|}
\hline Model & $\mathrm{R}$ & R Square & Adjusted R Square & Std. Error of the Estimate \\
\hline 1 & $.596^{\mathrm{a}}$ & .355 & .331 & .604 \\
\hline
\end{tabular}

Sumber: Data Primer yang diolah, 2021 

http://journal.univetbantara.ac.id/index.php/jbfe

Pada tabel 5 koefisisen determinan (Adjusted $R^{2}$ ) menjelaskan bahwa variabel independen yang terdiri sikap, motivasi, dan lingkungan menjelaskan variabel niat berwirausaha sebesar $33,1 \%$, selain itu masih terdapat variabel sebesar $66,9 \%$ yang menjelaskan niat berwirausaha.

Tabel 6. Hasil Uji F (X1,X2,X3 Terhadap Y)

\begin{tabular}{|l|l|}
\hline F Hitung & Sig. \\
\hline 15.021 & $.000^{\mathrm{b}}$ \\
\hline
\end{tabular}

Sumber: Data Primer yang diolah, 2021

Tabel 7. Hasil Uji t

\begin{tabular}{ll}
\hline $\mathrm{t}$ & Sig. \\
\hline 2,396 & .019 \\
4,225 & .000 \\
.690 & .492 \\
\hline
\end{tabular}

Sumber: Data Primer yang diolah, 2021

Dari pengujian di atas menunjukkan hasil bahwa variabel sikap terhadap niat berwirausaha, menghasilkan nilai t sebesar 2.396 dan pada signifikansinya $0,019<0,05$, maka dapat disimpulkan sikap berpengaruh positif dan signifikan terhadap niat berwirausaha. Variabel motivasi terhadap niat berwirausaha nilai t sebesar 4.225 dan pada signifikansinya $0,000<0,05$, berarti bahwa motivasi berpengaruh positif dan signifikan terhadap niat berwirausaha. Variabel lingkungan terhadap niat berwirausaha menghasilkan nilai t sebesar 0.690 dan nilai signifikansinya 0,492 > 0,05, maka dapat disimpulkan bahwa lingkungan tidak berpengaruh signifikan terhadap niat berwirausaha

\section{Pembahasan}

\section{Sikap berpengaruh positif terhadap niat berwirausaha}

Hasil penelitian menunjukkan bahwa sikap berpengaruh positif terhadap niat berwirausaha. Semakin kuat bentuk penilaian, perasaan, respon, serta tindakan seseorang terhadap kewirausahaan, maka semakin kuat kebulatan tekad seseorang untuk menjadi seorang wirausaha. Hal ini sesuai dengan hasil penelitian Sumadi \& Sulistyawati (2017), yang menunjukkan bahwa sikap berpengaruh positif dan signifikan terhadap niat berwirausaha.

\section{Motivasi berpengaruh positif terhadap niat berwirausaha}

Hasil penelitian ini menunjukkan bahwa motivasi berpengaruh positif dan signifikan terhadap niat berwirausaha. Semakin kuat dorongan dari dalam atau dari luar terhadap seseorang untuk berwirausaha, maka semakin tinggi keinginan orang tersebut untuk berwirausaha. Hal ini sesuai dengan hasil penelitian Sumadi \& Sulistyawati (2017), 

http://journal.univetbantara.ac.id/index.php/jbfe

yang menunjukkan bahwa motivasi berpengaruh positif dan signifikan terhadap niat berwirausaha.

\section{Lingkungan tidak berpengaruh secara signifikan terhadap niat berwirausaha}

Hasil penelitian ini menunjukkan bahwa lingkungan tidak berpengaruh signifikan terhadap niat berwirausaha. Lingkungan tidak mempengaruhi tinggi rendahnya niat berwirausaha di kalangan mahasiswa strata 1 (S1) di wilayah Kabupaten Sukoharjo. Hal tersebut dimungkinkan karena niat berwirausaha tidak dipengaruhi oleh keluarga, teman, atau tokoh panutan, tetapi dipengaruhi oleh sikap dan motivasi masing-masing mahasiswa. Hasil penelitian ini tidak sesuai dengan penelitian Sumadi \& Sulistyawati (2017), yang menunjukkan bahwa lingkungan berpengaruh positif dan signifikan terhadap niat berwirausaha.

Tabel 8. Kesimpulan Hipotesis

\begin{tabular}{|l|l|}
\hline Hipotesis & Kesimpulan \\
\hline H1: Sikap berpengaruh signifikan dan positif terhadap & Didukung \\
niat berwirausaha & \\
H2: Motivasi berpengaruh signifikan dan positif & Didukung \\
terhadap niat berwirausaha & \\
$\begin{array}{l}\text { H3: Lingkungan tidak berpengaruh signifikan terhadap } \\
\text { niat berwirausaha }\end{array}$ & Tidak Didukung \\
\hline
\end{tabular}
Sumber: Data Primer yang diolah, 2021

\section{KESIMPULAN, KETERBATASAN DAN SARAN}

Dari analisis data yang telah diperoleh dalam penelitian ini, maka dapat diambil kesimpulan sebagai berikut :

1. Sikap berpengaruh positif dan signifikan terhadap niat berwirausaha mahasiswa perguruan tinggi di wilayah Kabupaten Sukoharjo. H1 didukung.

2. Motivasi berpengaruh positif dan signifikan terhadap niat berwirausaha mahasiswa perguruan tinggi di wilayah Kabupaten Sukoharjo. H2 didukung.

3. Lingkungan tidak berpengaruh signifikan terhadap niat berwirausaha mahasiswa perguruan tinggi di wilayah Kabupaten Sukoharjo. H3 tidak didukung.

Keterbatasan Penelitian

1. Keterbatasan penelitian, hasil penelitian ini tidak bisa digeneralisasikan untuk perguruan tinggi di wilayah Kabupaten Sukoharjo, karena sampel penelitiannya tidak memenuhi sampel seluruh perguruan tinggi di wilayah 
http://journal.univetbantara.ac.id/index.php/jbfe

Kabupaten Sukoharjo, sebab hanya mendapat responden dari tiga perguruan tinggi di Wilayah Kabupaten Sukoharjo.

2. Keterbatasan dalam penyebaran kuesioner penelitian ini tidak bisa dilakukan secara langsung bertemu dengan responden dan melakukan wawancara langsung karena pandemi Covid-19.

Saran

Saran yang diberikan pada penelitian ini adalah :

1. Saran untuk peneliti selanjutnya

a. Disarankan untuk peneliti selanjutnya agar mendatangi secara langsung semua tujuh perguruan tinggi di Kabupaten Sukoharjo, untuk mendapatkan responden yang bisa mewakili mahasiswa semua perguruan tinggi di wilayah Kabupaten Sukoharjo, agar hasilnya dapat digeneralisasikan untuk semua mahasiswa perguruan tinggi di wilayah Kabupaten Sukoharjo.

b. Penelitian selanjutnya diharapkan dapat menyebarkan kuesioner secara langsung, agar dapat menjelaskan secara langsung kuesioner dan agar bisa melakukan wawancara secara langsung dengan responden.

2. Saran untuk perguruan tinggi yang dijadikan objek penelitian

a. Untuk meningkatkan niat berwirausaha di kalangan mahasiswa, maka perguruan tinggi perlu meningkatkan sikap pada mahasiswa. Untuk meningkatkan sikap, misalnya dengan cara melatih mahasiswa terlibat dalam suatu proses secara keseluruhan, misalnya melatih merancang produk, membuat produk, menjual produk, sampai mengevaluasi produk.

b. Untuk meningkatkan niat berwirausaha di kalangan mahasiswa, maka perguruan tinggi perlu meningkatkan motivasi berwirausaha pada mahasiswa, misalnya dengan cara memfasilitas, melatih dan memberi kebebasan para mahasiswa untuk berwirausaha sesuai minat bakatnya. 


\section{DAFTAR PUSTAKA}

Aidha, Z. (2016). Pengaruh Motivasi Terhadap Minat Berwirausaha Mahasiswa Fakultas Kesehatan Masyarakat Universitas Islam Negeri Sumatera Utara. JUMANTIK (Jurnal Ilmiah Penelitian Kesehatan) 1(1), 42-59.

Coulibaly, S. K. (2018). Economic globalization entrepreneurship, and development . Technological Forecasting and Sosial Change, 127, 271- 280.

Fourqoniah, F. (2015). Pengaruh Adopsi Jejaring Sosial Terhadap Intensi Berwirausaha Mahasiswa Program Sarjana di Indonesia. Jurnal Pendidikan Bisnis dan Manajemen. Volume 1.No.3, 150-159.

Havidz Aima, d. (2020). Effect Of Global Mindset And Entrepreneurial Motivation To Entrepreneurial Self- Efficacy And Implication To Entrepreneurial Intention. DIJDBM Vol.1,Issue. 2.

Hutagalung, B. (2017). The effect of entrepreneurship education and family environtment towards students' entrepreunerial motivation . International Journal of Economic Research, 14(20).

Jaya, I.P.B. (2016). Pengaruh Norma Subjektif, Efikasi Diri, Dan Sikap Terhadap Intensi Berwirausaha Siswa SMKN Di Denpasar. E- Jurnal Manajemen Unud. Volume. 5, No.3.

Kumalasari, K. (2013). Pengaruh Motivasi dan Hasil Belajar Kewirausahaan Terhadap Minat Berwirausaha Siswa Kelas XII di Smk Negeri 4 Purworejo. Oikonomia: Jurnal Pendidikan Ekonomi, 2(2).

Listyawati, I. H. (2017). Pengaruh Sikap, Norma Subjektif, dan Kontrol Keperilakuan Terhadap Niat Berwirausaha Pada Mahasiswa di Yogyakarta . JBMA. Volume IV. No. 1., .

Mahfud .Tuatul, d. (2020). The influence of social capital and entrepreneurial attitude orientation on entrepreneurial intentions: the mediating role of psychological capital. European Research.

Ma'sumah. N. (2018). Pengaruh Sikap, Norma Subjektif Dan Kontrol Perilaku Persepsi Terhadap Niat Berwirausaha Siswa.Economic Education Analysis Journal. 7 (1)

Mustaqim, M. (2017). Membangun Intensi Wirausaha Mahasiswa: Studi Pada Mahasiswa Prodi MBS dan ES STAIN Kudus. EQUILIBRIUM: Jurnal Ekonomi Syariah, 5(2).

Naim, W. (2016). Faktor- faktor memengaruhi niat berwirausaha mahasiswa . Jurnal Ekonomi Modernisasi Vol.12, No.3, , 134-149.

Nurshito, S. (2013). Analisis Pengaruh Interaksi Pengetahuan Berwirausaha dan Efikasi Diri Terhadap Intensi Berwirausaha. Kiat Bisnis 5(2), 148-158.

Piartini, P. M. (2019). Analisis Model Hubungan Sikap Dan Norma Subjektif Dengan Niat Berwirausaha Pada Mahasiswa Universitas Udayana . E-Jurnal Manajemen, Vol. 8, No. 11 . 
http://journal.univetbantara.ac.id/index.php/jbfe

Riana, P. T. (2020). Pengaruh Motivasi Berwirausaha, Pengendalian Diri, dan Lingkungan Keluarga Terhadap Niat Berwirausaha. E-Jurnal Manajemen Manajemen, Vol. 9, No., 4, 1594- 1613.

Rosmiati, J. D. (2015). Sikap, Motivasi, dan Minat Berwirausaha Mahasiswa. JMK.17. No. 1 .

Samuel, T. (2013). Familial factors, personality traits and self efficacy AS determinant of entrepreneurial intention among vocation based collage of education students in Oyo State, Nigeria. Internasional Journal of The African Symposium. 13(2), 6676.

Shidiq, F. (2020). Pengaruh Literasi Ekonomi,Sikap, dan Keluarga terhadap Niat Berwirausaha Mahasiswa Pendidikan Tata Niaga Universitas Negeri Surabaya. Jurnal Pendidikan Tata Niaga(JPTN).

Sipakoly, L. P. (2019). Pengaruh Sikap dan Motivasi Terhadap Niat Berwirausaha Studi Pada Mahasiswa Jurusan Akuntansi Politeknik Negeri Ambon. Jurnal Maneksi Vol 8, No.,2.

Space, W. (2014). International Standart Classification of Occupations (ISO). Encylopedia of Quality of Life and Well-Being Research, .

Sugiyono. (2006). Metode Penelitian Kuantitatif, Kualitatif, dan $R \& d$. Bandung : Alfabeta.

Suharto. A.K. (2021). Pengukuran Minat Berwirausaha Menggunakan Self Efficacy, Lingkungan dan Pendidikan Kewirausahaan Pada Mahasiswa FEB Universitas Muhammadiyah Metro. Jurnal Bisnis Darmajaya, Vol . No.1

Sulaeman. (2021, 4 mei 2021). Menkop Teten: Wirausaha Indonesia Kalah Dibanding Thailand dan Malaysia. Retrieved from merdeka.com: https://www.merdeka.com/uang/menkop-teten-wirausaha-indonesia-kalahdibanding-thailand-dan-malaysia.html

Sulistyawati, A. R. (2017). Pengaruh Sikap, Motivasi, dan Lingkungan Terhadap Niat Kewirausahaan . E-Jurnal Manajemen Unud, Vol. 6, No.2,, 1007-1029.

Tama, A. (2010). Analisis faktor- faktor yang memotivasi Mahasiswa yang berkinginan menjadi Entrepreuner. E- Jurnal Universitas Diponegoro,5(2),, 207- 218.

Wibowo. (2011). Manajemen Kinerja . Jakarta : PT. Raja Grafindo Persada.

Zain, Z. M. (2010). Entrepreneurship intention among Malaysian business students . Canadian Social Science, 6(3), 34-44. 


\section{INSTRUMEN PENELITIAN}

\section{A. VARIABEL NIAT BERWIRAUSAHA}

Niat berwirausaha adalah kebulatan tekad seseorang untuk menjadi seorang wirausaha.

\begin{tabular}{|l|l|l|l|l|l|l|}
\hline No & \multicolumn{1}{|c|}{ Pernyataan } & STS & TS & N & S & SS \\
\hline 1. & $\begin{array}{l}\text { Saya memiliki keinginan untuk menjadi } \\
\text { seorang wirausaha setelah lulus kuliah }\end{array}$ & & & & \\
\hline 2. & $\begin{array}{l}\text { Saya lebih suka menjadi wirausaha dan } \\
\text { mendirikan usaha sendiri dibandingkan } \\
\text { menjadi karyawan di perusahaan }\end{array}$ & & & & & \\
\hline 3. & $\begin{array}{l}\text { Saya memperkirakan dapat memulai usaha } \\
\text { dalam waktu 1-3 tahun kedepan }\end{array}$ & & & & \\
\hline
\end{tabular}

\section{B. VARIABEL SIKAP}

Sikap adalah penilaian, perasaan, respon serta tindakan terhadap suatu objek.

\begin{tabular}{|r|l|l|l|l|l|l|}
\hline No & \multicolumn{1}{|c|}{ Pernyataan } & STS & TS & S & SS \\
\hline 1. & $\begin{array}{l}\text { Saya memiliki keinginan untuk menjadi } \\
\text { mandiri }\end{array}$ & & & & \\
\hline 2. & $\begin{array}{l}\text { Saya memiliki keinginan mendapatkan } \\
\text { penghasilan yang besar }\end{array}$ & & & & \\
\hline 3. & $\begin{array}{l}\text { Saya memiliki keinginan memiliki } \\
\text { kebebasan dalam menentukan arah } \\
\text { wirausaha }\end{array}$ & & & & \\
\hline 4. & $\begin{array}{l}\text { Saya menyukai pekerjaan dengan } \\
\text { keterlibatan yang tinggi dalam keseluruhan } \\
\text { proses kegiatannya }\end{array}$ & & & & \\
\hline
\end{tabular}

\section{VARIABEL MOTIVASI}

Motivasi adalah dorongan atau keinginan untuk tercapai suatu tujuan.

\begin{tabular}{|r|l|l|l|l|l|l|}
\hline No & \multicolumn{1}{|c|}{ Pernyataan } & STS & TS & N & S & SS \\
\hline 1. & $\begin{array}{l}\text { Saya memiliki kepercayaan diri yang besar } \\
\text { dalam berwirausaha }\end{array}$ & & & & \\
\hline 2. & $\begin{array}{l}\text { Saya mempunyai ide yang inovatif dan } \\
\text { kreatif dalam berwirausaha }\end{array}$ & & & & \\
\hline 3. & $\begin{array}{l}\text { Saya memiliki jiwa kepemimpinan dalam } \\
\text { berwirausaha }\end{array}$ & & & & \\
\hline 4. & $\begin{array}{l}\text { Saya mempunyai efektifitas dan efisiensi } \\
\text { dalam berwirausaha }\end{array}$ & & & & \\
\hline 5. & $\begin{array}{l}\text { Saya memiliki keinginan yang berorientasi } \\
\text { pada masa depan }\end{array}$ & & & & \\
\hline
\end{tabular}

\section{VARIABEL LINGKUNGAN}

Lingkungan adalah lingkungan terbagi menjadi dua, lingkungan primer dan sekunder.

\begin{tabular}{|c|l|c|c|c|c|c|}
\hline No & \multicolumn{1}{|c|}{ Pernyataan } & STS & TS & N & S & SS \\
\hline 1. & $\begin{array}{l}\text { Saya memiliki keluarga sebagai acuan saya } \\
\text { menjadi seorang wirausaha }\end{array}$ & & & & & \\
\hline 2. & $\begin{array}{l}\text { Saya mempunyai teman sebagai acuan saya } \\
\text { menjadi seorang wirausaha }\end{array}$ & & & & \\
\hline
\end{tabular}


Journal of Business Finance and Economic (JBFE)

P-ISSN: 2746-6906

Volume 2, Nomor 1, Juni 2021

E-ISSN: 2746-6914

http://journal.univetbantara.ac.id/index.php/jbfe

\begin{tabular}{|c|l|l|l|l|l|}
\hline 3. & $\begin{array}{l}\text { Saya mendambakan ingin seperti tokoh } \\
\text { panutan saya, sehingga saya memiliki } \\
\text { keinginan untuk menjadi seorang wirausaha }\end{array}$ & & & & \\
\hline
\end{tabular}

